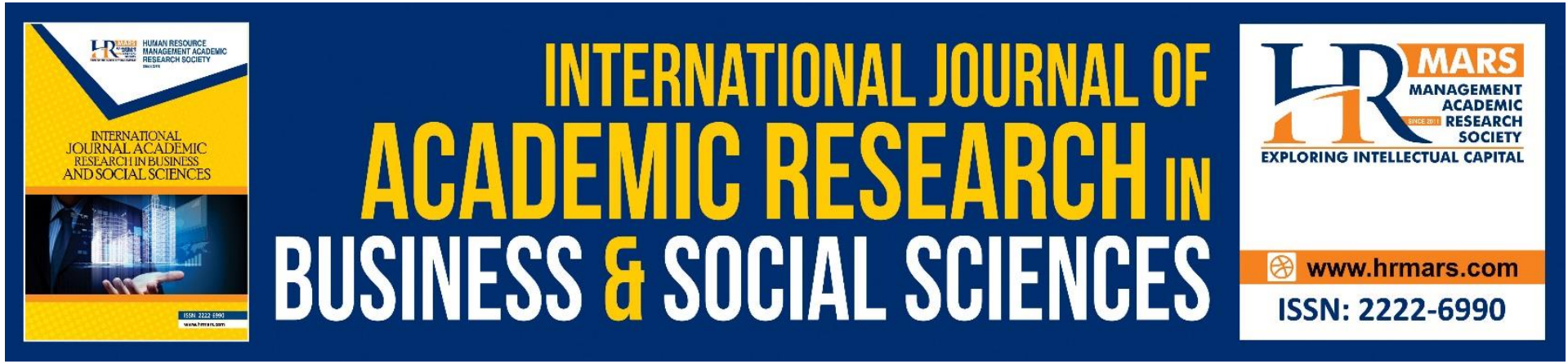

\title{
Employees' Innovativeness in Manufacturing Industry: A Case Study from a Japanese Firm
}

Kesavan Nallaluthan, Logaiswari Indiran, Bathmavathy Dalayga \& Shathees Baskaran

To Link this Article: http://dx.doi.org/10.6007/IJARBSS/v11-i8/10420

DOI:10.6007/IJARBSS/v11-i8/10420

Received: 01 June 2021, Revised: 27 June 2021, Accepted: 19 July 2021

Published Online: 03 August 2021

In-Text Citation: (Nallaluthan et al., 2021)

To Cite this Article: Nallaluthan, K., Indiran, L., Dalayga, B., \& Baskaran, S. (2021). Employees' Innovativeness in Manufacturing Industry: A Case Study from a Japanese Firm. International Journal of Academic Research in Business and Social Sciences, 11(8), 26-50.

Copyright: (c) 2021 The Author(s)

Published by Human Resource Management Academic Research Society (www.hrmars.com)

This article is published under the Creative Commons Attribution (CC BY 4.0) license. Anyone may reproduce, distribute, translate and create derivative works of this article (for both commercial and non-commercial purposes), subject to full attribution to the original publication and authors. The full terms of this license may be seen at: http://creativecommons.org/licences/by/4.0/legalcode

Vol. 11, No. 8, 2021, Pg. 26 - 50

Full Terms \& Conditions of access and use can be found at http://hrmars.com/index.php/pages/detail/publication-ethics 


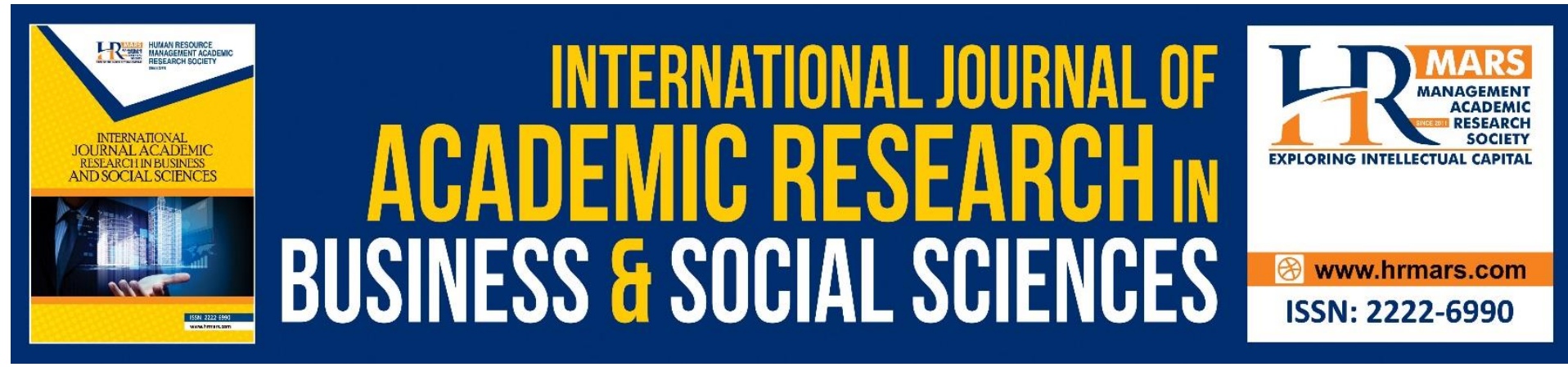

\title{
Employees' Innovativeness in Manufacturing Industry: A Case Study from a Japanese Firm
}

\author{
Kesavan Nallaluthan ${ }^{1}$, Logaiswari Indiran², Bathmavathy \\ Dalayga $^{3}$ \& Shathees Baskaran ${ }^{4}$ \\ ${ }^{1}$ Universiti Pendidikan Sultan Idris, Malaysia, ${ }^{2,4}$ Universiti Teknologi Malaysia, Malaysia, \\ ${ }^{3}$ Institut Tadbiran Awam Negara Bukit Kiara, Malaysia
}

\begin{abstract}
This study aims to examine the relationship between technical knowledge, workspace culture, and employees' innovativeness at a Japanese manufacturing firm. The theoretical model based on the social cognitive theory approach to employee innovativeness was developed. To answer the research questions, two hypotheses were formulated with moderating effect of workspace culture. Online survey questionnaires were distributed to these Japanese manufacturing employees. A total of 477 employees of all levels were involved in this study, making an overall 22.71 percent response rate. This study utilized the Partial Least SquaresStructural Equation Modelling (PLS-SEM) to establish the validity and reliability of the measurement model and structural model to test the relationships. The findings of the study showed that technical knowledge has significant influences on employee innovativeness and workspace culture has a moderating role in the relationship between technical knowledge towards employees' innovativeness. The findings offered several theoretical and practical implications to a selected Japanese firm and its policymakers. The limitations of the study are addressed and recommendations for future research work are also offered.
\end{abstract}

Keywords: Technical Knowledge, Workspace Culture, Employees' Innovativeness

\section{Introduction}

Globally, manufacturing firms, who prefer to create the groundwork for long-term success, are continuously evolving. They attempt exchange at the proper factor in time to impervious their financial survival. Therefore it is vital to comprehend how a firms' capacity to innovate can be improved, there are manifold ideas on that theme to be located in the literature (Amin, 2015; Ha et al., 2016; Mitchell-Ketzes, 2003). Innovation in this experience describes a new, technically possible product or process, which generates a financial cost (Bertola \& Teunissen, 2018). Moreover, Slåtten (2014) described that all innovation pastimes can be traced returned to the conduct of employees. Further, that makes the personnel the middle factor of interest if manufacturing corporations choose to enhance their innovation capability (De Jong \& Den Hartog, 2007). Employees' can nourish innovation or may want to even avoid it. This Exposé is constructed around the query of which private competencies and characteristics allow a worker to be innovative. Besides the definition of 'innovative employees', the differentiation of simple and specialist information is additionally included. 
Therefore, in this study, we more often than not targeted employees' innovativeness in manufacturing companies which is extraordinarily wished if the association avenue to implements new applied sciences greater toward enterprise four which used to be incredibly prompted at some stage in the Covid-19 pandemic. Moreover, take a look at consequences from technical understanding and workspace subculture toward employees' innovativeness at chosen Japanese manufacturing firm primarily based in Malaysia.

The world was affected by the COVID-19 outbreak that struck Malaysia. As opposed to an increase of 4.3 percent in 2019, GDP performance for 2020 decreased by 5.6 percent. (DOSM, 2020). Growth in the services sector was negative for the fifth year in a row with a decrease of 5.5 percent ( 6.1 percent) ( 3.8 percent). Industry 4.0 is brought in by the new concept of decline in the manufacturing sector, which reflects an important aspect of employees learning technological knowledge.

Thus, there has been an increased focus on employee innovativeness, which is increasingly seen as an important criterion for technology adoption since we are in the midst of the revolutionary upheaval of our lives and working styles. The exact impact of this shift on different businesses and countries is impossible to predict. What is different, though, is that we understand this transition is unlike anything we have before witnessed because of how fast and wide-ranging it is. As a result, the technical expertise and work environment of the manufacturing firm were equally crucial to facilitate the firm's goal of adopting new technologies.

Many observers view these alterations as opening up a whole new age of development, transformation, and new opportunities. Manufacturing companies cause nations and governments to reassess their approach to manufacturing and the effect it has on the economy (Jabbour et al., 2020). The nations of the world are devoting a growing amount of resources to creating sophisticated manufacturing capabilities by putting a significant emphasis on top-notch technological infrastructure and high-quality education (Martyakova \& Gorchakova, 2019). These things are done by making it easier for manufacturing companies to adopt the latest technology, helping them get ahead of the competition, and boosting their financial security.

Before the Industrial Revolution, it was steam and water power that allowed the industrialization of production processes, thereby laying the foundation for the first industrial revolution. Electric power and mass manufacturing processes were two factors that aided in the development of the second industrial revolution. The third industrial revolution began with the introduction of information technology and automation. In the wake of a spectrum of different technologies, the fourth industrial revolution is erupting based on more blurry physical, digital, and biological environments. The fourth industrial revolution, often known as Industry 4.0, integrates new design, manufacturing, operation, and maintenance processes to alter the way things are made, used, and maintained. The benefits are wide-ranging, including reducing operations, procedures, supply chain management, and the use of energy in industries (Oztemel \& Gursev, 2020; Vaidya et al., 2018).

The global geography of industrial rivalry is altered with the introduction of Industry 4.0, resulting in a reduced competitive edge for regions that are cost-advantaged by utilizing 
cheap labor (Simon et al., 2018). Its countries and corporations that are ahead in emphasizing Industry 4.0 technology and processes that will have an advantage over competitors around the world (Ghobakhloo \& Fathi, 2020). To remain competitive, you have to be able to adjust in response to developments in the market and new technology. However, industry 4.0 implementation is disputed in manufacturing since the roles of manufacturing employees must be a central factor. Employees' creativity serves as a significant characteristic in identifying as important for supporting industry 4.0 in manufacturing industries. Furthermore, to address these gaps, we surveyed employees at a manufacturing firm in Malaysia with a focus on a Japanese firm.

The central concept in the domain of entrepreneurial orientation has turned out to be innovativeness because it is essential for strategic orientation, entrepreneurial orientation can be thought of as a firm with a strategic orientation, and in this latter case, companies with a strategic orientation have their management approach affected by various aspects of entrepreneurship such as decision-making, working concepts, and managerial approaches (Huang \& Wang, 2011). In addition, Innovation enables firms to grow and is crucial to the country's economy (Zainol \& Ayadurai, 2011; Sahasranamam \& Sud, 2016). However, according to Covin and Slevin (2002), it is not only business founders or managing directors that must be entrepreneurial. The entire firm, including employees, must have a similar mindset (Sahasranamam \& Sud, 2016). Behaving with these mindsets will lead the company to losses since competitors can take advantage of opportunities if the company fails to do so (Burgelman, 1983b). This means that the entire business must work together if the firm is to succeed, and only the top staff or shareholders can guide the organization towards success. To support their business performance and growth, each employee, combined with the company's managing directors or business owners, must be an entrepreneur, as well as creative and imaginative (Covin \& Slevin, 2002; Sahasranamam \& Sud, 2016). The study conducted by Antoncic and Hisrich (2001) revealed that employee participation is critical to the growth of the business since they provide fresh and unique ideas.

Another method to promote employees' innovativeness is to place more importance on technical expertise within manufacturing industries in the future. Understanding modern technology, its working, and the latest advancements all come under the heading of technical knowledge. Understanding a technological topic is enabled by the study of this subject. The ability to grasp and comprehend any issue or problem regardless of form or format and apply that understanding to any of a variety of settings is called technical knowledge. For example, if you know how to use the hidden functions on your machine touch panel can work to troubleshoot the machine yourself without close supervision, and understand the basics of the production process that makes them function, then you have a high level of technological knowledge.

Manual employees' are paid for performing physical activities or waiting for others to support them to solve problems, whereas technical employees are considered to think for a living. Unlike other employees, technical knowledge employees at manufacturing firms are distinguished from other employees by their capacity to tackle complicated challenges. As more firms move toward a collaborative workplace that allows more control to their employees, the number of Technical knowledge employees has grown (Davenport, 2005). At a manufacturing firm, technical knowledge employees quickly readily identify who has it. 
Their day-to-day activities included taking the initiative and meeting deadlines. More open to working according to the orders given to them by their superiors.

The culture in which the workplace is organized is important to organizational theories (Chu, Wang, \& Lai, 2019). A firm's management culture is the mixture of values, beliefs, and practices that is dominant inside the firm. This definition further classifies values, norms, beliefs, attitudes, and assumptions as patterns of values, norms, beliefs, attitudes, and assumptions that exist, but have not been explicitly expressed, and hence influence organizational behaviors and results (Akta et al., 2011). Decision-making and the level of authority are influenced by the office culture (Childe et al., 2016). Organizational elements such as performance standards, attitudes, and behavior norms need to be in place at the outset (Maamari \& Saheb, 2018). It does not solely rely on the individual behaviors and attitudes of employees, but also the attitudes and behaviors of the organization as a whole (Aksoy et al., 2014). However, a workplace culture can significantly impact the efficacy and efficiency of tactics (Chu et al., 2019). Through the use of its controls, the employee attitudes and behavior are directed and shaped towards organizational activities (Pawirosumarto et al., 2017). A workplace culture encourages employees to have a clear sense of who they are and what they are allowed to do in society (Ibrahim et al., 2017). Despite that, one of the arguments among previous studies is how workplace culture should be studied, with some experts believing to emphasize it in manufacturing firms that rely on the innovativeness of employees.

Despite employees' innovativeness is one of the important keys for the manufacturing firm success. However, employees' innovativeness not only able to continue to support its manufacturing firm, but it also needs support from technical knowledge and workspace culture which also has a high possibility to support employees' innovativeness in manufacturing firms. As a consequence, the following research questions will be addressed in this study:

RQ1. What is the relationship between technical knowledge and employees' innovativeness?

RQ2. What is the moderating effect of workspace culture between technical knowledge and employees' innovativeness?

The current study examines samples of a Japanese firm from a variety level of job positions. The significance of this study is that it seeks to examine employees' innovativeness in terms of technical knowledge and workspace culture in the Japanese manufacturing firm. To gather data for the research, a questionnaire was circulated to all employees from diverse position levels in one selected Japanese manufacturing firm.

Five parts comprise the article, the first of which is an introduction. The second part is dedicated to the literature review, model specification, and hypothesis formulation. The third section focuses on the techniques used to perform the scientific study. The paper's fourth section contains the decision, and its fifth section contains the conclusion and limitation of this study. 


\section{Literature Review \\ Employee Innovativeness}

"Innovativeness" refers to the ability to find fresh and different ideas and ways of doing things (Lumpkin \& Dess, 1996; Morris et al., 2007; Boso et al., 2012). Creative destruction, a process that occurs when money is produced by introducing a new product or service, is also an expression used by Schumpeter (1942) who was the initial researcher who explained the necessity of innovation in the entrepreneurial process. A further characteristic that is shared by several organizational principles is that, even though a large number of principles influence the execution of an organization, Bueno and Ordonez (2004) observed that innovation was the distinguishing factor that assisted the organization to remain competitive throughout business advancement. Changes to an organization's capacity to react and adjust to both internal and external pressures influence how the work is scheduled and organized (Hull \& Hage, 1982). To look at the inspection of an entrepreneurial introduction, focus on the fact that the business writing was developing through time. This was discovered by Covin and Miles (1999), who believe that an organization would not endure without advancement and the frequent replacement of older methods or goods that make current techniques or goods outmoded (Morris \& Kuratko, 2002). Finally, as stated by Edison et al (2013), whether or not innovation influences entrepreneurship depends on the context in which it is implemented (Tajeddini, 2011). The terms "product evolution," "process development," "engineering," "research and development," and "technical competence" can be used interchangeably with the terms "industrial expertise" and "industry experience" (Tajeddini \& Trueman, 2008). That is to say, in addition to that, Sharma and Dave (2011) found that the job of entrepreneurs is to drive innovation and hence concluded that entrepreneurs are responsible for value creation.

Accordingly, research centered on an employees' innovativeness might indicate their willingness to pursue new opportunities, to produce new ideas, and/or to start a process (Jong \& Hartog, 2010). This corresponds to Agarwal and Prasad (1998), in which they discuss how an employee is willing to discover new products, processes, methods, tasks, and technology and contributes to the performance of the company or industry (Janssen, 2005). They so indicate coaching, training, and assistance to help employees get the skills and confidence they need (Mikkelsen et al., 2002). The next step is to create consistent practices and organizational culture that is in harmony with other organizations' policies and procedures (Chow, 2012). Using their innovative ideas and application in organizations that rely more on technical knowledge, employees contribute to entrepreneurial orientation (Agarwal \& Prasad, 1998). Manufacturing organizations are still experiencing issues, though, because industry 4.0 has been adopted so rapidly.

\section{Technical Knowledge}

The capacity to execute complex technical tasks in manufacturing is known as technical knowledge. There is a significant difference between technical knowledge and broad knowledge, such as learning about history or philosophy (Wiig, 1997). Some employees view technical knowledge as a specific collection of skills in the working environment, but others consider it an ever-evolving thing. Technical knowledge in manufacturing is frequently understood to refer to basic machine operating or troubleshooting skills in a production environment setting (Suzaki, 1987). Therefore, employees should add software and hardware skills to their resumes if they have them. As there is no particular technical skill required for 
the competencies like managerial experience or interpersonal skills, these are referred to as non-technical competencies.

Hence in manufacturing, to possess technical talents, one must also have theoretical knowledge, which can directly impact the capabilities of such skills. Additionally, in certain positions, relevant concepts of physics might be considered technical knowledge. This information directly applies to carrying out the particular technical tasks of that position. But knowledge doesn't have to involve theoretical material to be deemed technical. Even if employees don't know the underlying principles the computer is based on, they can still be regarded as technically proficient if they know how to use a computer (Handzic, 2011).

Because there is such a wide range of technical information, it is imperative to stay on target when sharing findings. Auto repair abilities are of little importance when trying to be hired as a manager while databasing and word processing know-how are important (Gerbin \& Drnovsek, 2020). Hence, the challenges occur in weather when employees' ability to perform more innovatively if they have the technical knowledge to overcome production problems.

\section{Workspace Culture}

The mind has stages such as expectancies, purposes, and mentalities, which are used to describe the behaviors, characteristics, and Workspace culture (Hofstede et al., 2005). To have the biggest impact, a comprehensive collective culture must include social characteristics that define how members of the population are socialized to be part of their particular social group (Anwar \& Jabnoun, 2006). Additionally, an implied connection exists between the workplace culture and the social culture; workplace culture is a subset of social culture (Lagrosen, 2003). (Pun \& Furlonge, 2009). Additionally, due to understanding how the organization's culture is an important building component, Demarest (1997); Davenport and Prusak (1998); Gold et al (2001) all identified the existence of the authoritative society as a necessary component for knowledge management and making the most of the available resources. The workplace culture was established by the morality, as well as personnel in the organization, the organizational structure, and the setting up of the workplace. Furthermore, workplace culture, referred to as an arrangement of shared importance held by organizational employees that recognizes one organization from another, is strongly associated with the notion of how members view their significance within the organization (Walker \& Aritz, 2015; Hartnell et al., 2016). This factor is linked to the following other ideas: workplace views on self-importance, organizational significance, qualities, convictions, standards, and practices. According to North and Kumta (2018), North and Kumta believe that their operations are a sense-production and control system that encourages employee cooperation. An organization with a good organizational culture could facilitate the success of the workplace by making it more suited and robust (Ibragimova et al., 2012; Greene et al., 2014; El-Said, 2015 ) to provide an empowering influence on knowledge management, organization culture should be recognized as an asset in the exploration. Finally, as far as a capability to promote learning, sharing among employees, and most importantly, to behave entrepreneurially, culture will further break down. However, according to Pun and Furlonge (2012), the adoption of manufacturing culture and implementation significantly increased the quality of job performances of manufacturing staff. While Messner (2013) believes that work culture contributes to employee commitment, management should also recognize people for their efforts (Prouska et al., 2016). Since this, one can assert that workspace culture is essential to 
the company. Nonetheless, there are challenges when it comes to the impact technical knowledge has on employee innovativeness in many firms.

\section{Social Cognitive Theory}

According to social cognitive theory, motivation, learning, and self-regulation all have social aspects (Schunk \& Usher, 2019). The conversation in this article is constrained to Bandura's social cognitive paradigm $(1986,1997,2001)$. This theory has been used in many areas of study, including psychology, education, business, and health. Predictions from the theory have been tested in different situations in numerous locations. There are several persons, nevertheless, who helped build, test, and popularise the notion in a variety of different techniques together with Zimmerman, Schunk, Pajares, and Usher.

At one time, prior versions of social cognition theory were called "social mastering theories" and "motivational theories of human behavior," because the studies tended to focus on motivational and social elements. In other words, two distinct motivations have been added to Rotter's theory: expectation, which is trust in the chance of getting a given reinforcer after a specific behavior, and reinforcement value, which represents how many people favor specific effects among a range of alternatives. In the context of Bandura's theory, these two variables experience some relationship to cost and consequence expectancy.

Before Bandura's social learning theory, social learning theorists stressed the impact of learning that takes place through observed (vicarious) practice without the involvement of overt overall performance (Bandura \& Walters, 1963; Bandura, 1977). According to Bandura, people should pay attention to a model, and then mimic the model's conduct. The preliminary research on mannequin modeling found many variables, including perceived mannequin competency, mannequin status, and perceived likeness to the mannequin, that influence motivation in viewers (Bandura \& Walters, 1963). Employees' technical expertise was highly dependent on the penalties they were anticipated to get for implementing innovative activities. Social interactions between fashions and observers produce cognitive assumptions called consequence expectations. Therefore, in this study contributions, technical knowledge considered under learning and workspace culture as motivational which focused more towards employees' innovativeness.

\section{Model Specifications and Hypotheses}

Hypotheses were developed based on the conceptual model of social cognitive and its variables were also utilized in this study (i.e. technical knowledge, workspace culture, and employees' innovativeness).

\section{Technical knowledge and employees' innovativeness}

Innovativeness in the workplace means that employees rapidly absorb new ideas (Agarwal \& Prasad 1998). The idea proposed by Parasuraman (2000) is that employees' innovativeness depends on the ability to be a pioneer (a pioneer is the first mover) and a thought leader. Actions taken in the early stages of the adoption of an idea serve to describe individuals as "innovative." Any new idea is laden with uncertainty, risks, and imperfections (Bowers \& Khorakian, 2014; Janssen. 2003; Thiesse, 2007). The idea put forth by Rogers (1995) is that early adopters of innovation can handle greater levels of uncertainty. Also, they can adapt themselves or the workplace to learn new technological expertise, resulting in benefits such 
as being more willing to learn about the company's technology (Janssen et al., 2004). In light of this, people with characteristics of entrepreneurial innovation may lead to an increase in manufacturing firm's entrepreneurial orientation. A quickly summarised summary of this theory is that those with higher levels of employee innovation are better able to deal with more exposure to technical information infirm.

Innovativeness is the propensity for a business to design, create, or implement new features or components or use well-known components in novel ways. To innovate, a company must get new knowledge, disseminate it, and implement it (Moorman \& Miner, 1998). As a result, innovation performance is almost certainly affected by knowledge management (Subramaniam \& Youndt, 2005). Providing individuals and groups with the opportunity to do all three of these is the aim of effective knowledge management (Argote et al., 2003). The innovation process yields dynamic creation and sharing of information, whereas retaining organizational processes become more rigid concerning where to store this knowledge. For these reasons, in this research, we concentrate on how information creation and sharing influence a company's inventiveness. Recombining the current stock of knowledge to generate new knowledge offers companies many chances for knowledge development (Argote et al., 2003). Employees have the potential to create new knowledge to solve challenges by using knowledge-creating activities (Sabherwal \& Becerra-Fernandez, 2003). Managers and employees of a business can make use of new information and capabilities to bring forth fresh ideas, increase productivity, and develop new products and services (Grant, 1996). This means that corporations value the mechanisms that give them access to new technologies. Therefore, knowledge generation mechanisms, when effectively utilized, provide an inclination for companies to constantly develop new goods and processes (Kmieciak \& Michna, 2018; Zieba \& Zieba 2014).

Thus, our first hypothesis is as follows:

H1 Technical knowledge positively affects employee innovativeness.

\section{Moderating Effect of Workspace Culture}

Lack of empirical study on workplace culture and interpersonal relationships among enthusiastic and hard-working employees is the norm (Jaskyte \& Dressler, 2005; Lizardo, 2006). Our literature research shows that the available studies are restricted in Asia, notably Vietnam when it comes to the relationship between workspace culture and employees' inventiveness. For the time being, the only data available on some facets of innovation is on how innovative an organization is and whether that leads to an innovative culture. Limiting the generalized knowledge on employees' innovativeness has been implemented. Cultural values enable people to exhibit their creativity (Barbosa, 2014). Previous research has shown that workplace culture positively correlates with employees' innovation (Katarzyna, 2014; Westwood \& Low, 2003). Several studies that looked at the relationship between workspace design and invention from the software sector found that favorable working conditions are associated with higher levels of innovation (Shahzad et al., 2017). Creative tasks are most facilitated when all four components of creativity are present, according to Amabile (2013). Workplace flexibility helps ensure constant innovation (Ghosh, 2015). Industry 4.0 technology, for example, promotes a flexible, efficient, and creative work atmosphere. Firms place a high value on their employees' creativity, and they provide numerous good 
advantages such as rewards, flexible work hours, and company services. Workers are supported to be creative and bring unique concepts to life (Fernandez \& Moldogaziev, 2013).

The overall company culture and workplace environment might moderate the individual performance of employees. A new policy shows that the company culture has norms of good behavior and principles of trust implemented that are understood by the employee to increase the employee's productivity. According to Siengthai et al. (2019), a beneficial effect on innovative thinking is found in workspace culture. To promote an office culture shift toward an adhocracy culture, which improves creativity and whose value drivers include innovative outputs, transformation, and adaptability among employees, they recommend a workplace strategy in which authority is decentralized. To summarise, our second hypothesis can be expressed as follows:

$\mathrm{H} 2$ Working culture positively moderates the relationships between technical knowledge and employee innovativeness

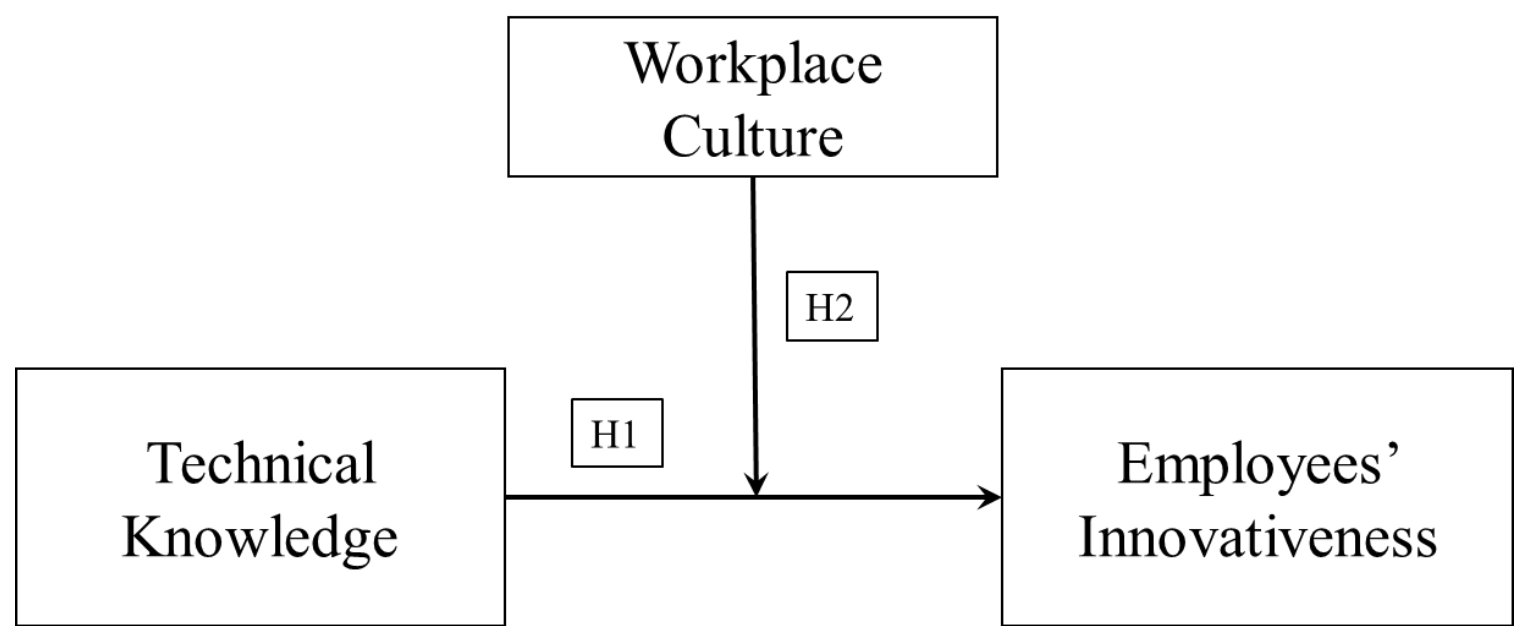

Figure 1: A research framework

The study attempts to explore the relationship between employee innovativeness, technical knowledge, and working culture. This section provides descriptions and justifications of the methods and measures that were used in the study; the study is descriptive and quantitative.

\section{Population and Sample Size}

In this cross-sectional research data were collected from one of the selected Japanese manufacturing firms based in Malaysia. According to these Japanese firm human resource department, there were 2100 registered employees in the year 2019. As the population of the study is finite, the Yamane (1973) formula was used to determine the minimum sample size. According to the formula, the sample size for the present study should be 399 at $\pm 5 \%$. Below is the formula we used:

$$
n=\frac{N}{1+N(e)^{2}}
$$


In this formula $n=$ Sample size; $N=$ Total population; $e=$ Precision level

$$
n=\frac{2100}{1+2100(e)^{2}}
$$

So as per the calculation of the formula, the minimum sample size is 336 . The sample size of the present study was 477 respondents. Roscoe (1975) defined a standard for deciding the optimal sample size, specifying that it should be greater than 30 but less than 500 respondents (Sekaran \& Bougie, 2016). Comrey and Lee (1992), on the other hand, argued that a sample size of more than 200 respondents is sufficient. Saunders and Lewis (2017) make a similar argument, arguing that any sample size larger than 200 is adequate for drawing a fair inference in social science studies. As a result, data were collected via online survey questionnaires conveniently distributed to one selected Japanese manufacturing firm employee (July 2019 - September 2019). The current sample size of the study is adequate as it meets the other sampling techniques as well.

\section{Questionnaire Development}

This study modified a previous questionnaire on entrepreneurial orientation by Baskaran (2017) to employees at Cement manufacturers in Johor, Malaysia. The data were collected through online survey questionnaires distributed to all levels of employees in selected Japanese manufacturing firms based in Malaysia. The data were gathered using the 5-point Likert scale (1-strongly disagree, 2-disagree, 3-neutral, 4-agree, 5-strongly agree). A Likert scale is the most suitable instrument for analyzing respondents' viewpoints and views (Sekaran \& Bougie, 2016). Additionally, a five-point Likert scale is preferred because it reduces respondent anxiety while increasing the uniqueness of the results. We used two distinct methods to determine reliability and validity. One was in charge of the instruments and styles, while the other was in charge of the respondents. Statistical analyses were used to assess the instruments' and models' reliability and validity, while a longitudinal check was used to determine the respondent population. Two main sections were used in the questionnaires included in this analysis. The first segment of the questionnaire requested demographic details about the respondents, including their gender, age, and current position. Sociodemographic questions were used to reach out to the target audience while preserving the respondents' authenticity and validity. We used these sociodemographic questions to validate the features of a group. We did not disclose the names of any respondents to them upon receipt of their responses through the Google form sheet to maintain confidentiality. Thus, the demographic search helped in assessing the reliability and legitimacy of the respondents.

\section{Data Analysis \\ Respondents Profile}

Various respondents' demographic profiles are provided in Table 1. This demographic information includes the working period in the organization, such as age, gender, academic levels as well as the respondents' department within the organization. 
Table 1

Respondents Profile

\begin{tabular}{|c|c|c|c|}
\hline Particular & Variables & Frequency & Percentage \\
\hline & Male & 116 & 25.9 \\
\hline \multirow{4}{*}{ Sex } & Female & 361 & 74.1 \\
\hline & Total & 477 & 100 \\
\hline & $20-30$ & 207 & 43.4 \\
\hline & $31-40$ & 161 & 33.8 \\
\hline \multirow[t]{6}{*}{ Age } & $41-50$ & 93 & 19.5 \\
\hline & $>50$ & 16 & 3.3 \\
\hline & Total & 477 & 100 \\
\hline & $0-5$ Years & 201 & 42.3 \\
\hline & 6-10 Years & 76 & 15.9 \\
\hline & 11-15 Years & 67 & 14.1 \\
\hline \multirow[t]{8}{*}{ Work period } & $16-20$ Years & 59 & 12.3 \\
\hline & 21-25 Years & 52 & 10.8 \\
\hline & $>25$ Years & 22 & 4.6 \\
\hline & Total & 477 & 100 \\
\hline & HR \& Finance & 11 & 2.3 \\
\hline & Import/Export \& IT & 7 & 1.5 \\
\hline & Store \& Shipping & 16 & 3.4 \\
\hline & T\&D / ESH & 7 & 1.5 \\
\hline \multirow[t]{8}{*}{ Department } & QA \& CS & 69 & 14.4 \\
\hline & Engineering & 85 & 17.8 \\
\hline & Production & 257 & 53.8 \\
\hline & Others & 25 & 5.3 \\
\hline & Total & 477 & 100 \\
\hline & Master & 8 & 1.6 \\
\hline & Degree & 85 & 17.8 \\
\hline & Diploma & 39 & 8.2 \\
\hline \multirow[t]{4}{*}{ Academic } & Professional Cert. & 31 & 6.5 \\
\hline & Certificate & 225 & 47.2 \\
\hline & Others & 89 & 18.7 \\
\hline & Total & 477 & 100 \\
\hline \multirow[t]{9}{*}{ Position } & Operator & 272 & 57.0 \\
\hline & Line Leader & 45 & 9.4 \\
\hline & Supervisor & 25 & 5.2 \\
\hline & Technician & 39 & 8.2 \\
\hline & Engineer & 48 & 10.1 \\
\hline & Officer & 24 & 5.0 \\
\hline & Executive & 13 & 2.7 \\
\hline & Manager & 11 & 2.4 \\
\hline & Total & 477 & 100.0 \\
\hline
\end{tabular}

The table displays that about 74.1 percent of the employees were females while the remaining were males. This revealed that the industry is female dominant, it has been proven by the majority of respondents from operational level employees' were female. In addition, 
the employees' circulation in terms of age range shows that at least half of the employees are in the age range of 20 to 30 years old while the remaining employees make up the other 50 percent and very fewer respondents make up to an age range of over 30 years old. Next, this shows that the younger workforce with an age range of 20 to 30 years old possesses a higher propensity to take risks and carry out work with a good extent of encouragement, strength, and self-responsibility to accomplish organizational purposes and tasks. Further, employee working period categories ranged between 0 to 5 years (42.3 percent), 6 to 10 years (15.9 percent), and the rest of the employees who worked over 10 years ( 41.8 percent). Next, as far as a departmental level is involved, oftenest of the employees distributed across the production, technical and engineering departments. At least 53.8 percent of employees make up the production while the continuing employees were from the human resource and finance, quality assurance and customer service, store and shipping, engineering and import, export and information technology, and other departments. In view of the educational background, most of the employees were certificate holders. Next, employees with a certificate made up about 47.2 percent of the total employees. In addition, this is in line whereby employees with certification possess the strength to inspire the manufacturing industries. The other educational levels made up about 18.7 percent, is the second-largest educational level among employees due to some foreign employees attached in this manufacturing firm. Last, regarding the position level, about 57 percent of the employees were operators with 9.4 percent as line leaders, which reveals that most of the employees are from operational level positions.

PLS (partial least squares) modeling was used to assess the measurement and structural model as the SmartPLS 3.3.3 version (Ringle et al., 2015) is an example of a PLS statistical model without the normality assumption as survey research is non-Gaussian (Chin et al., 2003).

Our data were obtained from a single source, and hence we initially checked for Common Method Bias and Collinearity, as well as suggested by Kock and Lynn, 2012 and Kock, 2015. This method entails finding all of the variables that interact with a certain common variable and then finding the smallest value for the variance inflation factor (VIF) of those variables. If the VIF is equal to or smaller than 5 , then there is no bias from the single-source data. The results showed a VIF of less than 3.5, which suggests single-source bias is not a problem with our data, as shown in Table 2.

Table 2 Full Collinearity Testing

\begin{tabular}{ccc}
\hline Inn & Tech & Cul \\
\hline 3.288 & 3.245 & 3.444 \\
\hline
\end{tabular}

Note: $\quad$ Inn $=$ Employees' Innovativeness, Tech $=$ Technical Knowledge, Cul $=$ Workspace Culture

\section{Measurement Model}

We used Anderson and Gerbing (1988) as a guide to doing a two-step test on the model. We first conducted a validity and reliability test of the measurement model by using Hair et al. (2019) and Ramayah et al. (2018) to see if the instruments used matched the guidelines, then we conducted the structural model to evaluate the hypothesis developed. 
We used loadings, average variance extracted (AVE), and the composite reliability for the measurement model (CR). The loadings should be at least 0.5 , the AVE must be at least 0.5 , and the CR must be at least 0.7. In our result shows, all the AVEs are above 0.5 , whilst all the CRs are above 0.7. Moreover, all loadings were more than 0.708 (Hair et al., 2019). Based on the information provided in Table 3, we have examined the validity and reliability of the two constructs of technical knowledge and workspace culture to understand how they relate to employees' innovativeness.

Using the HTMT criterion proposed by Henseler et al (2015) and modified by Franke and Sarstedt (2019), we proceeded to examine discriminant validity in step 2 . The mode mild threshold for the HTMT values is 0.90 ; the tighter criterion is 0.85 . We can conclude that the respondents recognized that the 2 notions are separate, as Table 4 shows, because the values of HTMT were all lower than the tougher threshold of $<0.85$. When the validity and reliability of the measurement items are combined, they both show that the measurements are valid and reliable.

Table 3

Measurement Model for the Constructs

\begin{tabular}{llccc}
\hline Constructs & Items & Loadings & AVE & CR \\
\hline Employees' Innovativeness & EI1 & 0.832 & 0.673 & 0.954 \\
& EI2 & 0.866 & & \\
EI3 & 0.814 & & \\
EI4 & 0.856 & & \\
EI5 & 0.831 & & \\
& EI6 & 0.781 & & \\
EI7 & 0.829 & & \\
& EI8 & 0.800 & & \\
& EI9 & 0.850 & & \\
\hline Technical Knowledge & El10 & 0.743 & & \\
& TK1 & 0.88 & 0.752 & \\
& TK2 & 0.891 & & \\
& TK3 & 0.892 & & \\
TK4 & 0.837 & & \\
& TK5 & 0.835 & & \\
\hline Workspace Culture & EC1 & 0.859 & 0.688 & \\
& EC2 & 0.778 & & \\
& EC3 & 0.876 & & \\
& EC4 & 0.876 & & \\
& EC5 & 0.752 & & \\
\hline
\end{tabular}


Table 4

Discriminant Validity (HTMT)

\begin{tabular}{lccc}
\hline & 1 & 2 & 4 \\
\hline Working Culture & & & \\
\hline Employees' Innovativeness & 0.827 & & \\
\hline Technology Knowledge & 0.884 & 0.786 & \\
\hline
\end{tabular}

\section{Structural Model}

We calculated multivariate skewness and kurtosis as indicated by Hair et al (2017) and Cain et al (2017). We found that our data followed the recommendation of Hair et al (2019) and used a 5,000-sample re-sample bootstrapping procedure to derive the path coefficients, standard errors, $t$-values, and p-values of the structural model (Ramayah et al., 2018). Hahn and Ang (2017) have criticized p-values and advised adopting a combination of criteria instead. The data summarised in Table 5 displays the criteria we've used to examine the hypothesis.

The first thing we did was to look at the effect of the two predictors on employees' innovativeness. After we did this, we found that the correlation coefficient was $0.628\left(Q^{2}=\right.$ 0.423), which demonstrates that all of the variances in employees' innovativeness are explained by the two predictors. A positive correlation between technical knowledge and the innovativeness of employees has been found, so $\mathrm{H} 1$ is supported.

An impact size of $0.26,0.13$, and 0.02 indicates that the external latent variable has a large, moderate, and slight effect on the endogenous latent variable, correspondingly (Cohen, 1988). As a model becomes more complicated, the value will fluctuate. In actuality, though, technical expertise proved to be a weak predictor. In sum, for overall company innovativeness, $\mathrm{R}^{2}$ is 0.651 , with technical knowledge having a moderating effect on workspace culture accounting for 65.1 percent of the variance.

Stone-Geisser's $Q^{2}$ value, derived by the application of blindfolding technique on endogenous construct with reflective measurement model specification is utilized to make predictions on the structural model (Hair et al., 2016). For the blindfolding procedure, the sample size was 477 and the omission distance (D) was 7. As long as the sample size divided by $D$ is not rounded identically, 5 to 10 is an acceptable value for D (Chin, 2010). To calculate the predictive significance of the model, Hair et al (2016) advised the use of the cross-validated redundancy approach. This study concluded that the model's predictive power was demonstrated by an experiment conducted with a $Q^{2}$ value of 0.423 , which was bigger than zero.

Finally, table 6 summarised the findings from the analysis of the moderating influence of workspace culture on the relationships between technical knowledge and employees' innovation. The moderating influence of workspace culture has a profound impact on the link between technical knowledge employees' innovativeness. The $f^{2}$ value of 0.067 , or technical knowledge with a low effect size, implies that future studies should explore this construct using more reliable measures. These findings show that technical knowledge employees' innovativeness is positively affected by workspace culture and in light of Figure 3 , the effect 
of interaction is positive, showing an increase in the innovation commitment of technical knowledge employees in a Japanese manufacturing firm.

Table 5

Hypothesis testing (Direct effects).

\begin{tabular}{llllllll}
\hline & & & & $\mathrm{t}-$ & $\mathrm{p}-$ & & \\
Hypothesis & Relationship & Std.Beta & Std.Error & value & value & $\mathrm{f}^{2}$ & Decision \\
\hline H1 & $\begin{array}{l}\text { Technology } \rightarrow \\
\text { Innovative }\end{array}$ & 0.188 & 0.052 & 6.524 & $\mathrm{p}<0.05$ & 0.119 & \\
\hline
\end{tabular}

${ }^{*} \mathrm{p}<0.05(\mathrm{t}=1.645)$.

Table 6

Hypothesis testing (Moderating effects).

\begin{tabular}{llllllll}
\hline Hypothesis & & & & $\mathrm{t}-$ & $\mathrm{p}-$ & & \\
& Relationship & Std.Beta & Std.Error & value & value & $\mathrm{f}^{2}$ & Decision \\
\hline & $\begin{array}{l}\text { Technology* } \\
\text { Culture } \rightarrow \\
\text { Innovative }\end{array}$ & -0.166 & 0.024 & 6.904 & $\mathrm{p}<0.05$ & 0.067 & \\
\hline
\end{tabular}

$* \mathrm{p}<0.05(\mathrm{t}=1.645)$.

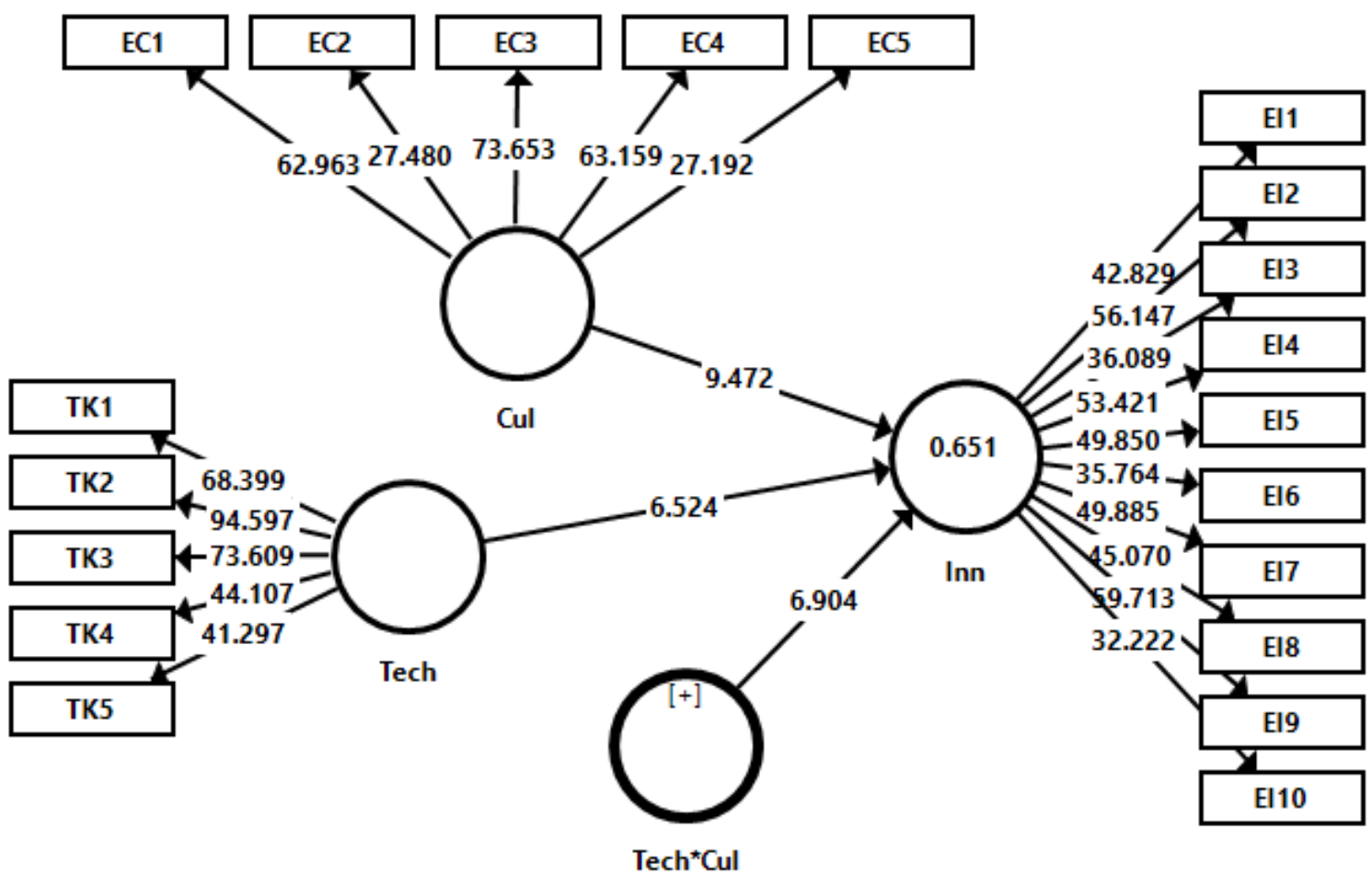

Figure 2: Structural model 


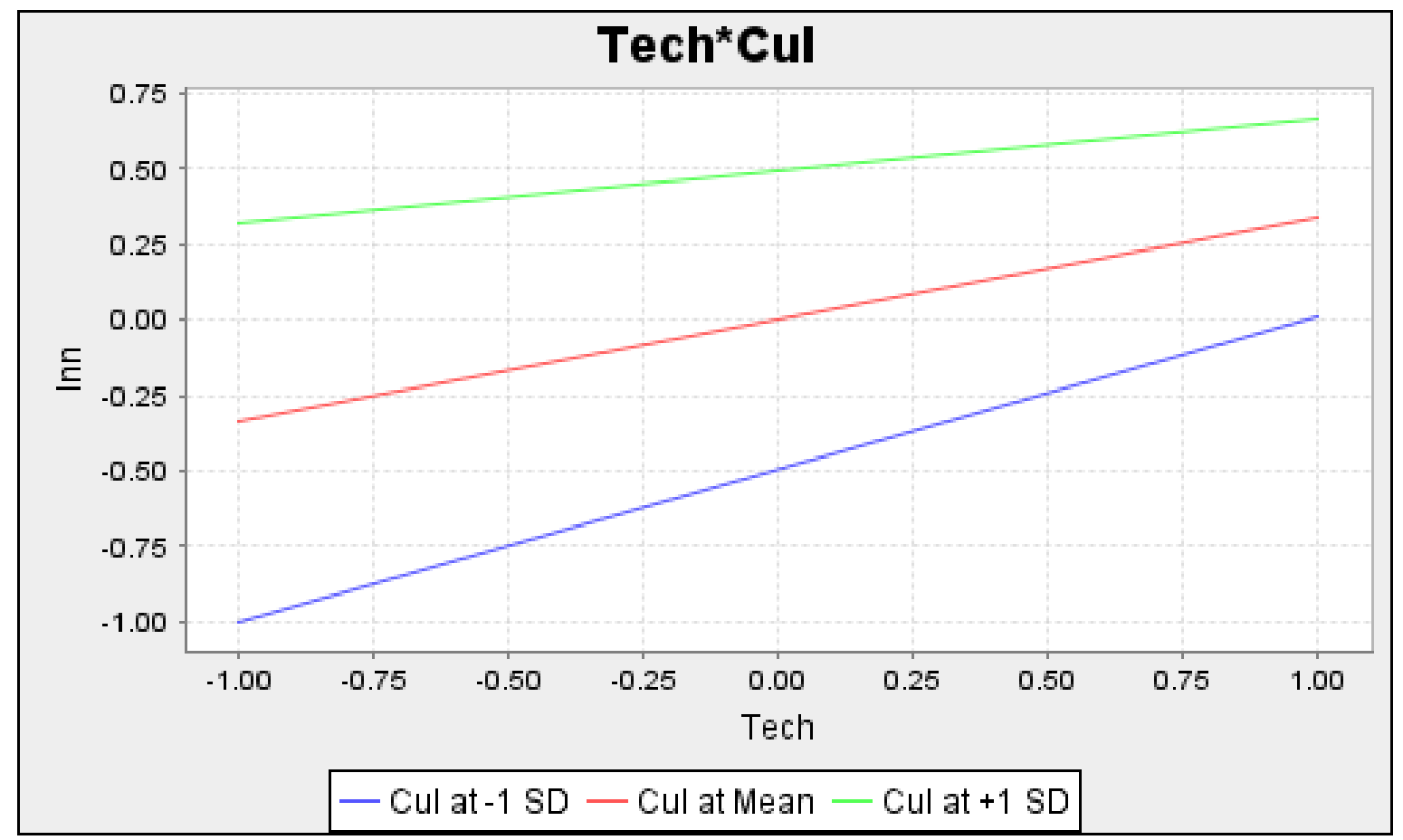

Figure 3: Moderation effect

As further recommended by Shmueli et al. (2019), a holdout sample-based process is proposed called PLSpredict. This tool utilizes the PLS-Predict method along with a 10-fold procedure to confirm whether or not case-level predictions are relevant. Shmueli and colleagues (2019) concluded that if all of the item differences were lower than there was considerable predictive power, while if they were all greater, predictive significance was not validated. Based on Table 5, our model's predictive power is stronger than the LM model, and all of the mistakes made by the PLS model were lower than those of the LM model.

Table 5

PLS-Predict

\begin{tabular}{|c|c|c|c|c|}
\hline & PLS & LM & & \\
\hline Item & RMSE & RMSE & PLS-LM & $\mathrm{Q}^{2}$ _predict \\
\hline EI1 & 0.746 & 0.807 & -0.061 & 0.509 \\
\hline EI2 & 0.784 & 0.887 & -0.103 & 0.455 \\
\hline EI3 & 0.677 & 0.773 & -0.096 & 0.537 \\
\hline El4 & 0.702 & 0.798 & -0.096 & 0.409 \\
\hline EI5 & 0.686 & 0.802 & -0.116 & 0.417 \\
\hline EI6 & 0.741 & 0.821 & -0.08 & 0.477 \\
\hline EI7 & 0.778 & 0.833 & -0.055 & 0.435 \\
\hline El8 & 0.791 & 0.874 & -0.083 & 0.466 \\
\hline E19 & 0.706 & 0.749 & -0.043 & 0.475 \\
\hline El10 & 0.68 & 0.766 & -0.086 & 0.504 \\
\hline
\end{tabular}

\section{Discussion}

The current study investigated the impact of technical knowledge on employees' innovativeness in one of the selected Japanese manufacturing firm based in Malaysia which is under planning to implement industry 4.0 at their firm. Therefore, this research was 
conducted to getting know about their technical knowledge to support their innovativeness if their top management brings in elements of industry 4.0 at their firm.

The current research discovered an important positive relationship between technical knowledge and employees' innovativeness. The study yielded a t-value of 6.554 and a $\beta$-value of 0.118 . This demonstrates a direct link between technical knowledge and employees' innovativeness. Therefore, it shows technical knowledge would increase employees' innovativeness in a selected Japanese firm. Additionally, the current study's findings are consistent with those of previous research (Kmieciak \& Michna, 2018; Mathew et al., 2011; Zieba \& Zieba 2014).

In the case moderating effect of workspace culture, a substantial association between employees' innovativeness was discovered, with a t-value of 6.459. A $\beta$-value of -0.166 indicates that workspace culture is negatively related to employees' innovativeness. These findings are opposite with past studies such as Swailes (2000) and Siengthai et al, (2019). As a result, the findings indicate that decreased workspace culture correlates with increased employees' innovativeness at this firm. Therefore

\section{Conclusion}

The current research adds to the literature related to employees' innovativeness as well as technical knowledge by investigating the moderating role of workspace culture. The findings of this current study support our first hypotheses on the positive effects of technical knowledge and employees' innovativeness. In addition, the second hypothesis negatively moderating the effects of workspace culture on employees' innovativeness at selected Japanese firm which based in Malaysia.

Therefore, we can conclude that at this Japanese firm's top management can implement new technologies element which related with industry 4.0 such as smart manufacturing, artificially intelligent, robotics, big data, and others because their employees' willingness to adopt new technical knowledge to support their firm. Moreover, this firm's top management must focus on technical knowledge training and development for their employees' which is can lead towards their innovativeness. However, based on workplace culture results, it shows that culture changes at this firm will gave negative impacts on employees' innovativeness because the currently implemented culture might be not suitable for their employees. So, managers must be more focused on any cultural changes in their firm because any mistakes in decision making in their workspace culture might be given a huge impact on their employees' innovativeness, such as hiring unfit employees', working time changes, benefit reduced and others.

\section{Limitation and Recommendation}

Limitations of this learn about include: (1) the researcher unfold questionnaires in a chosen Japanese firm in Malaysia, so the lookup used to be biased primarily based on current practices, (2) the respondents have been much less cautious in analyzing the statement of the research as a supply of principal data, (3) respondents who answered with a perfunctory and dishonest. However, it can be decreased by way of searching at the reply to the means in the back of the statement. Therefore, for in addition research, it can be anticipated to gather greater records via distributing questionnaires in an extra firm incomparable nature of the industry with extra various respondents to discover a greater complete result. 


\section{Theoretical and Contextual Contribution}

This research has made significant contributions to the body of knowledge on employees' innovativeness in the selected Japanese manufacturing which is based in the Malaysia sector by attempting to add to existing theories in knowledge management, knowledge about the factors affecting the employees' innovativeness for change regarding technical knowledge implementation. It has identified a list of factors as composite variables which are affecting the employees' innovativeness for implementing technical knowledge within selected Japanese firms may be examined. On the other hand, from a theoretical perspective, this study highlights all of the workspace culture decreasing the relationship between technical knowledge and employees' innovativeness for change or foster within the manufacturing industry context.

For some time now, this Japanese manufacturing has been and will continue to be the basis of the financial system in Malaysia. Consequently, the research findings have many institutional consequences for practitioners and policy-makers in raising the quality of knowledge management and the workspace culture in implementing innovativeness in the firm. Firstly, top management must be the aware current situation in this firm should establish a good technical training program for their employees because effective knowledge transfer and knowledge sharing among them able improve their innovativeness (Abdullah et al., 2014). In addition, top management will motivate their employees through the implementation of an appropriate technical knowledge program to engage in implementing knowledge management practices for those who contribute to their practices. Employees are also committed to enforcing knowledge sharing.

Moreover, top management ought to furnish their members with preparing on commitment in the varied technical knowledge of accomplishment, which leads to strengthening feelings of their innovativeness. Thirdly, the most important of workspace culture initiatives is a knowledge management strategy that has been concerned in previous studies, an extensive effort should be put forth to establish a supportive environment because the change in workspace culture might be having negative impacts on employees' innovativeness.

\section{References}

Abdullah, N. H., Ping, L. L., Wahab, E., \& Shamsuddin, A. (2014, September). Perception on training and employee innovativeness: An evidence from small firms. In 2014 IEEE International Conference on Management of Innovation and Technology (76-80). IEEE.

Agarwal, R., \& Prasad, J. (1998). A conceptual and operational definition of personal innovativeness in the domain of information technology. Information systems research, 9(2), 204-215.

Aksoy, M., Apak, S., Eren, E., \& Korkmaz, M. (2014). Analysis of The Effect of Organizational Learning-Based Organizational Culture on Performance, Job Satisfaction and Efficiency: A Field Study in Banking Sector. International Journal of Academic Research, 6(1).

Aktaş, E., Çiçek, I., \& Kıyak, M. (2011). The effect of organizational culture on organizational efficiency: The moderating role of organizational environment and CEO values. Procedia-Social and Behavioral Sciences, 24(1), 1560-1573.

Amabile, T.M. (2013). Componential Theory of Creativity. In: Kessler, E.H., Ed., Encyclopedia of Management Theory, Sage Publications, London, 134-139. 
Amin, M. (2015). The effect of entrepreneurship orientation and learning orientation on SMEs' performance: an SEM-PLS approach. J. for International Business and Entrepreneurship Development, 8(3), 215.

Anderson, J. C., \& Gerbing, D. W. (1988). Structural equation modeling in practice: A review and recommended two-step approach. Psychological Bulletin, 103(3), 411-423.

Antoncic, B., \& Hisrich, R. D. (2001). Intrapreneurship: Construct refinement and cross cultural validation. Journal of business venturing, 16(5), 495-527.

Anwar, S. A., \& Jabnoun, N. (2006). The development of a contingency model relating national culture to total quality management. International Journal of Management, 23(2), 272.

Argote, L., McEvily, B., \& Reagans, R. (2003). Introduction to the special issue on managing knowledge in organizations: Creating, retaining, and transferring knowledge. Management science, 49(4), v-viii.

Bandura, A. (1986). Social foundations of thought and action: A social cognitive theory. Englewood Cliffs, NJ: Prentice Hall.

Bandura, A. (1997). Self-efficacy: The exercise of control. New York: Freeman.

Bandura, A. (2001). Social cognitive theory: An agentic perspective. Annual Review of Psychology, 52, 1-26.

Bandura, A., \& Walters, R. H. (1963). Social learning and personality development. New York: Holt, Rinehart \& Winston.

Bandura, A., Adams, N. E., \& Bayer, J. (1977). Cognitive processes mediating behavioral change. Journal of Personality and Social Psychology, 35, 125-139.

Barbosa, M. C. S. (2014). Culturas infantis: contribuições e reflexões. Revista Diálogo Educacional, 14(43), 645-667.

Baskaran, S. (2017). Clarifying the Influence of Management Support in Creating Entrepreneurial Orientation. The International Journal of Business \&Management, 5(2), 101-107.

Bertola, P., \& Teunissen, J. (2018). Fashion 4.0. Innovating fashion industry through digital transformation. Research Journal of Textile and Apparel, 22(4), 352-369.

Boso, N., Cadogan, J. W., \& Story, V. M. (2012). Complementary effect of entrepreneurial and market orientations on export new product success under differing levels of competitive intensity and financial capital. International Business Review, 21(4), 667681.

Bowers, J., \& Khorakian, A. (2014). Integrating risk management in the innovation project. European Journal of innovation management. 17 (1), 25-40.

Bueno, E., Ordonez de Pablos, P., \& Salmador Sanchez, M. P. (2004). Towards an integrative model of business, knowledge and organisational learning processes. International Journal of Technology Management, 27(6-7), 562-574.

Burgelman, R.A. (1983). A process model of internal corporate venturing in the diversified major firm. Administrative Science Quarterly, 28(2), 223-244.

Cain, M. K., Zhang, Z., \& Yuan, K. H. (2016). Univariate and multivariate skewness and kurtosis for measuring nonnormality: Prevalence, influence and estimation. Behavior Research Methods, 49(5), 1716-1735.

Chin, W. W., Marcolin, B. L., \& Newsted, P. R. (2003). A partial least squares latent variable modeling approach for measuring interaction effects: results from a monte carlo simulation study and an electronic-mail emotion adoption study. Information Systems Research, 14(2), 189-217. 
Cohen, J. (1988). Statistical Power Analysis for the Behavioral Sciences (2nd ed.). Hillsdale, NJ: Lawrence Erlbaum Associates, Publishers

Chow, R. (2012). Entanglements, or transmedial thinking about capture. Duke University Press.

Comrey, A. L., \& Lee, H. B. (1992). Interpretation and application of factor analytic results. Comrey AL, Lee HB. A first course in factor analysis, 2, 1992.

Covin, J. G., \& Miles, M. P. (1999). Corporate entrepreneurship and the pursuit of competitive advantage. Entrepreneurship theory and practice, 23(3), 47-63.

Covin, J.G., \& Slevin, D.P. (2002). The entrepreneurial imperatives of strategic leadership, in Hitt, M.A., Ireland, R.D., Camp, S.M. and Sexton, D.L. (Eds), Strategic Entrepreneurship, Creating a New Mindset, Blackwell Publishers, $\quad$ Oxford, 309-327.

Davenport, T. H. (2005). Thinking for a living: how to get better performances and results from knowledge workers. Harvard Business Press.

Davenport, T. H., \& Prusak, L. (1998). Working knowledge: How organizations manage what they know. Harvard Business Press.

De Jong, J. P., \& Den Hartog, D. N. (2007). How leaders influence employees' innovative behaviour. European Journal of innovation management. 10(1), 41-64.

De Jong, J., \& Den Hartog, D. (2010). Measuring innovative work behaviour. Creativity and innovation management, 19(1), 23-36.

de Sousa Jabbour, A. B. L., Ndubisi, N. O., \& Seles, B. M. R. P. (2020). Sustainable development in Asian manufacturing SMEs: Progress and directions. International Journal of Production Economics, 225, 107567.

Demarest, M. (1997). Understanding knowledge management. Long range planning, 30(3), 374-384.

Department of Statistics Malaysia Official Portal. (n.d.). Retrieved March 17, 2021, from https://www.dosm.gov.my/v1/index.php?r=column/cthemeByCat\&cat=124\&bul_id=Q m82anlxSkxvRDJEWkQyZUJaQ0tDZz09\&menu_id=Tm8zcnRjdVRNWWIpWjRlbmtlaDk1 UT09

Edison, H., Bin Ali, N., \& Torkar, R. (2013). Towards innovation measurement in the software industry. Journal of Systems and Software, 86(5), 1390-1407.

El-Said, H. (2015). New approaches to countering terrorism: designing and evaluating counter radicalization and de-radicalization programs. Springer.

Fernandez, S., \& Moldogaziev, T. (2013). Using employee empowerment to encourage innovative behavior in the public sector. Journal of public administration research and theory, 23(1), 155-187.

Franke, G., \& Sarstedt, M. (2019). Heuristics versus statistics in discriminant validity testing: a comparison of four procedures. Internet Research, 29(3), 430-447.

Gerbin, A., \& Drnovsek, M. (2020). Knowledge-sharing restrictions in the life sciences: personal and context-specific factors in academia-industry knowledge transfer. Journal of Knowledge Management, 24(7), 1533-1557. https://doi.org/10.1108/JKM-11-20190651

Ghobakhloo, M., \& Fathi, M. (2020). Corporate survival in Industry 4.0 era: the enabling role of lean-digitized manufacturing. Journal of Manufacturing Technology Management, 31(1), 1-30.

Gold, A. H., Malhotra, A., \& Segars, A. H. (2001). Knowledge management: An organizational capabilities perspective. Journal of management information systems, 18(1), 185-214. 
Grant, R. M. (1996). Prospering in dynamically-competitive environments: Organizational capability as knowledge integration. Organization science, 7(4), 375-387.

Greene, C., Crumbleholme, L., \& Myerson, J. (2014). Sustainable cultures: engaging employees in creating more sustainable workplaces and workstyles. Facilities.

Ha, S. T., Lo, M. C., \& Ramayah, T. (2016). Decomposing market orientation and its relationship to innovativeness of SMEs in Malaysia: the moderating effects of market turbulence. J. for International Business and Entrepreneurship Development, 9(3), 273.

Hahn, E. D., \& Ang, S. H. (2017). From the editors: New directions in the reporting of statistical results in the Journal of World Business. Journal of World Business, 52(2), 125-126.

Hair, J. F., Thomas, G., Hult, M., Ringle, C. M., \& Sarstedt, M. (2017). A Primer on Partial Least Squares Structural Equation Modeling (2nd ed.). Thousand Oakes, CA: Sage.

Hair, J., Risher, J., Sarstedt, M.,\& Ringle, C. (2019), When to use and how to report the results of PLS-SEM. European Business Review, 31(1), 2-24.

Handzic, M. (2011). Integrated socio-technical knowledge management model: an empirical evaluation. Journal of Knowledge Management, 15(2), 198-211.

Hartnell, C. A., Kinicki, A. J., Lambert, L. S., Fugate, M., \& Doyle Corner, P. (2016). Do similarities or differences between CEO leadership and organizational culture have a more positive effect on firm performance? A test of competing predictions. Journal of Applied Psychology, 101(6), 846.

Henseler, J., Ringle, C., \& Sarstedt, M. (2015). A New Criterion for Assessing Discriminant Validity in Variance-based Structural Equation Modeling. Journal of the Academy of Marketing Science, 43(1), 115-135.

Hofstede, G., Hofstede, G. J., \& Minkov, M. (2005). Cultures and organizations: Software of the mind (Vol. 2). New York: Mcgraw-hill.

Hull, F., \& Hage, J. (1982). Organizing for innovation: Beyond Burns and Stalker's organic type. Sociology, 16(4), 564-577.

Ibragimova, B., Ryan, S. D., Windsor, J. C., \& Prybutok, V. R. (2012). Understanding the Antecedents of Knowledge Sharing: An Organizational Justice Perspective. Informing Science, 15.

Ibrahim, R., Boerhannoeddin, A., \& Kayode, B. K. (2017). Organizational culture and development: Testing the structural path of factors affecting employees' work performance in an organization. Asia Pacific Management Review, 22(2), 104-111.

Janssen, O. (2003). Innovative behaviour and job involvement at the price of conflict and less satisfactory relations with co-workers. Journal of occupational and organizational psychology, 76(3), 347-364.

Janssen, O., Van de Vliert, E., \& West, M. (2004). The bright and dark sides of individual and group innovation: A special issue introduction. Journal of organizational behavior, 25(2), 129-145.

Jaskyte, K., \& Dressler, W. W. (2005). Organizational culture and innovation in nonprofit human service organizations. Administration in social work, 29(2), 23-41.

Katarzyna, K. (2014). Marzec 68'w polskim kinie-o Różyczce Jana Kidawy-Błońskiego. Załq̨cznik Kulturoznawczy, (1), 242-258.

Kmieciak, R., \& Michna, A. (2018). Knowledge management orientation, innovativeness, and competitive intensity: evidence from Polish SMEs. Knowledge Management Research \& Practice, 16(4), 559-572.

Kock, N. (2015). Common method bias in PLS-SEM: A full collinearity assessment approach. International Journal of e-Collaboration, 11(4), 1-10. 
Kock, N., \& Lynn, G. S. (2012). Lateral collinearity and misleading results in variance-based SEM: An illustration and recommendations. Journal of the Association for Information Systems, 13(7), 546-580.

Lagrosen, S. (2003). Exploring the impact of culture on quality management. International Journal of Quality \& Reliability Management. 20 (4), 473-487.

Lizardo, O. (2006). How cultural tastes shape personal networks. American sociological review, 71(5), 778-807.

Lumpkin, G. T., \& Dess, G. G. (1996). Clarifying the entrepreneurial orientation construct and linking it to performance. Academy of management Review, 21(1), 135-172.

Maamari, B. E., \& Saheb, A. (2018). How organizational culture and leadership style affect employees' performance of genders. International Journal of Organizational Analysis. 26, 630-651

Martyakova, E., \& Gorchakova, E. (2019, June). Quality education and digitalization of the economy. In International Conference on the Industry 4.0 model for Advanced Manufacturing (212-218). Springer, Cham.

Mathew, M., Kumar, D., \& Perumal, S. (2011). Role of knowledge management initiatives in organizational innovativeness: Empirical findings from the IT industry. Vikalpa, 36(2), 31-44.

Messner, W. (2013). Effect of organizational culture on employee commitment in the Indian IT services sourcing industry. Journal of Indian Business Research. 5, 76-100.

Mikkelsen, A., Øgaard, T., Lind Øe, P. H., \& Olsen, O. E. (2002). Job characteristics and computer anxiety in the production industry. Computers in Human Behavior, 18(3), 223-239.

Mitchell-Ketzes, S. (2003). Optimising business performance through innovative workplace strategies. Journal of Facilities Management, 2(3), 258-275.

Moorman, C., \& Miner, A. S. (1998). Organizational improvisation and organizational memory. Academy of management Review, 23(4), 698-723.

Morris, M. H., \& Kuratko, D. F. (2002). Corporate entrepreneurship: Entrepreneurial development within organizations. South-Western Pub.

Morris, M. H., Coombes, S., Schindehutte, M., \& Allen, J. (2007). Antecedents and outcomes of entrepreneurial and market orientations in a non-profit context: Theoretical and empirical insights. Journal of Leadership \& Organizational Studies, 13(4), 12-39.

Neely, A., \& Hii, J. (1998). Innovation and business performance: a literature review. The Judge Institute of Management Studies, University of Cambridge, 0-65.

North, K., \& Kumta, G. (2018). Knowledge work (ers) in the digital age. In Knowledge Management,109-156. Springer, Cham.

Oztemel, E., \& Gursev, S. (2020). Literature review of Industry 4.0 and related technologies. Journal of Intelligent Manufacturing, 31(1), 127-182.

Parasuraman, A. (2000). Technology Readiness Index (TRI) a multiple-item scale to measure readiness to embrace new technologies. Journal of service research, 2(4), 307-320.

Pawirosumarto, S., Setyadi, A., \& Khumaedi, E. (2017). The influence of organizational culture on the performance of employees at University of Mercu Buana. International Journal of Law and Management. 59 (6), 950-963.

https://doi.org/10.1108/IJLMA-03-2016-0030

Prouska, R., Psychogios, A. G., \& Rexhepi, Y. (2016). Rewarding employees in turbulent economies for improved organisational performance: Exploring SMEs in the SouthEastern European region. Personnel Review. 45 (6), 1259-1280. https://doi.org/10.1108/PR-02-2015-0024 
Pun, K. F., \& Jaggernath-Furlonge, S. (2009). Exploring culture dimensions and enablers in quality management practices: Some findings. Asian Journal on Quality. 10 (2), 57-76.

Pyöriä, P. (2005). The concept of knowledge work revisited. Journal of knowledge management. 9 (3), 116-127. https://doi.org/10.1108/13673270510602818

Ramayah, T., Cheah, J., Chuah, F., Ting, H., \& Memon, M. A. (2018). Partial Least Squares Structural Equation Modeling (PLS-SEM) using SmartPLS 3.0: An Updated Guide and Practical Guide to Statistical Analysis (2nd ed.). Kuala Lumpur, Malaysia: Pearson.

Ringle, C. M., Wende, S., \& Becker, J.-M. (2015). "SmartPLS 3." Boenningstedt: SmartPLS $\mathrm{GmbH}, \mathrm{http}: / /$ www.smartpls.com

Rogers, E. M. (1995). Diffusion of Innovations: modifications of a model for telecommunications. In Die diffusion von innovationen in der telekommunikation, 2538. Springer, Berlin, Heidelberg.

Roscoe, J. T. (1975). Fundamental research statistics for the behavioural sciences, New York: Holt.

Rotter, J. B. (1954). Social learning and clinical psychology. Englewood Cliffs, NJ: Prentice Hall. Ryan (Ed.). The Oxford handbook of human motivation (pp. 11-26). (2nd ed.). New York: Oxford University Press.

Sabherwal, R., \& Becerra-Fernandez, I. (2003). An empirical study of the effect of knowledge management processes at individual, group, and organizational levels. Decision sciences, 34 (2), 225-260.

Sahasranamam, S., \& Sud, M. (2016). Opportunity and Necessity Entrepreneurship: A Comparative Study of India and China. Academy of Entrepreneurship Journal, 2(1), 2140.

Saunders, M. N., \& Lewis, P. (2017). Doing research in business and management. Pearson.

Schunk, D. H., \& Usher, E. L. (2019). Social cognitive theory and motivation. In R. M.

Schunk, D. H., Meece, J. L., \& Pintrich, P. R. (2014). Motivation in education: Theory, research, and applications (4th ed.). Boston: Pearson Education.

Sekaran, U., \& Bougie, R. (2016). Research methods for business: A skill building approach. John Wiley \& Sons.

Sharma, A., \& Dave, S. (2011). Entrepreneurial orientation: Performance level. SCMS Journal of Indian Management, 8(4), 43.

Shmueli, G., Ray, S., Velasquez Estrada, J. M., \& Chatla, S. B. (2016). The Elephant in the Room: Predictive Performance of PLS Models. Journal of Business Research, 69(10), 45524564.

Shmueli, G., Sarstedt, M., Hair, J. F., Cheah, J. H., Ting, H., Vaithilingam, S., \& Ringle, C. M. (2019). Predictive Model Assessment in PLS-SEM: Guidelines for Using PLSpredict. European Journal of Marketing, 53(11), 2322-2347.

Siengthai, S., Swierczek, F., \& Bamel, U. K. (2019). The effects of organizational culture and commitment on employee innovation: evidence from Vietnam's IT industry. Journal of Asia Business Studies. 13, 719-742.

Simon, J., Trojanova, M., Zbihlej, J., \& Sarosi, J. (2018). Mass customization model in food industry using industry 4.0 standard with fuzzy-based multi-criteria decision making methodology. Advances in Mechanical Engineering, 10(3), 1-10.

Slåtten, T. (2014). Determinants and effects of employee's creative self-efficacy on innovative activities. International Journal of Quality and Service Sciences. 6(4), 326-347. https://doi.org/10.1108/IJQSS-03-2013-0013. 
Subramaniam, M., \& Youndt, M. A. (2005). The influence of intellectual capital on the types of innovative capabilities. Academy of Management journal, 48(3), 450-463.

Suzaki, K. (1987). New manufacturing challenge: Techniques for continuous improvement. Simon and Schuster.

Tajeddini, K. (2011). The effects of innovativeness on effectiveness and efficiency. Education, Business and Society: Contemporary Middle Eastern Issues. 4(1), 6-18. https://doi.org/10.1108/17537981111111238

Tajeddini, K., \& Trueman, M. (2008). The potential for innovativeness: a tale of the Swiss watch industry. Journal of Marketing Management, 24(1-2), 169-184.

Thiesse, F. (2007). RFID, privacy and the perception of risk: A strategic framework. The Journal of Strategic Information Systems, 16(2), 214-232.

Vaidya, S., Ambad, P., \& Bhosle, S. (2018). Industry 4.0 - A Glimpse. Procedia Manufacturing, 20, 233-238.

Walker, R. C., \& Aritz, J. (2015). Women doing leadership: Leadership styles and organizational culture. International Journal of Business Communication, 52(4), 452-478.

Westwood, R., \& Low, D. R. (2003). The multicultural muse: Culture, creativity and innovation. International journal of cross cultural management, 3(2), 235-259.

Wiig, K. M. (1997). Knowledge Management: An Introduction and Perspective. Journal of Knowledge Management, 1(1), 6-14. https://doi.org/10.1108/13673279710800682

Yamane, T. (1973). Statistics: an introductory analysis. New York: Harper \& Row.

Zainol, F. A., \& Ayadurai, S. (2011). Entrepreneurial Orientation and Firm Performance: The Role of Personality Traits in Malay Family Firms in Malaysia. International Journal of Business and Social Science, 2(1), 59-71.

Zieba, M., \& Zieba, K. (2014). Knowledge management critical success factors and the innovativeness of KIBS companies. Engineering Economics, 25(4), 458-465. 